Pak. j. sci. ind. res. Ser. A: phys. sci. 2020 63A(2) 94-100

\title{
Identify the Archaeological Research of Thatta District Through Geo-Spatial Technologies: A Case Study of Makli Graveyard and Banbhore Fort
}

\author{
Zia Ur Rehman ${ }^{a *}$, Asif Gul ${ }^{\mathrm{a}}$, Syed Jamil Hasan Kazmi ${ }^{\mathrm{a}}$ and Danish Ahmed \\ ${ }^{a}$ Department of Geography, University of Karachi-75270, Karachi, Pakistan \\ ${ }^{b}$ Department of Antiquities, Government of Sindh, Karachi, Pakistan
}

(received September 13, 2018; revised April 16, 2019; accepted April 17, 2019)

\begin{abstract}
Archaeological studies with the help of geographic information systems and remote sensing have been used in temporal, spatial, regional analysis and to investigate traditional and historical ways of human life. Remote sensing alludes to a wide variety of high-technology methods for collecting data pertaining to the physical or chemical properties of an archaeological site survey. The aim of this study is to identify the archaeological site of Makli graveyard and Banbhore fort through satellite images and explore the major land cover patterns on the southern part of Sindh province using geospatial technologies. Additional goals are to evaluate and visualize the Digital Elevation Model (DEM) for the southern part of Sindh province. A landsat-8 OLI / TIRS of $20^{\text {th }}$ December 2014 and a DEM image were used to classify land cover and artifacts at the site. The result indicates that historical monuments at Makli, and Banbhore fort, Thatta testify in an outstanding manner, to the civilization of the Sindh region. geographically, its location is vulnerable around the river. Banbhore has survived such threats and continued to flourish as the only and most important port of Sindh.
\end{abstract}

Keywords: GIS, remote sensing, historic environment, harapaa civilization.

\section{Introduction}

Detection, interpretation, documentation and monitoring of archaeological features are fundamental for understanding the historic environment, as well as maintaining and protecting cultural heritage. Archaeological features commonly survive as subsurface remains (e.g. ancient roads, ditches, ruined buildings) which can be evidenced as crop/soil marks and/or earthworks on historical photographs (Peppa et al., 2018). Many scientists have used the expediency of Geographic Information Systems (GIS) for archaeological analyses, predictive site location modeling and producing topographical site surveys. Although the use of GIS to investigate the spatial relationships among the site of archaeology, architecture and its geography has rarely been done (Lieff, 2006). Archaeological studies with help of GIS have been utilized in regional analysis (Moyes, 2002). In present day, GIS has become a tool to carry out research and analyze information about traditional geographical sciences. Remote sensing is also helpful to map and explore the large-scale underground relics more rapidly and economically than traditional archaeological technologies. It also helps to understand archaeological data and the historic environment of these sites.

*Author for correspondence; E-mail: ziarockies86@gmail.com
Archaeologists have realized the potential of GIS and remote sensing in archaeology. For example, aerial photography can detect phenomena on the surface associated with subsurface relics, while the use of infrared and thermal electromagnetic radiation can be used to detect underground archaeological remains. Some few published studies have shown the importance of using high-resolution satellite images in archaeology and heritage management (Nsanziyera et al., 2018). There is no doubt about the value and existing capability of remote sensing to allow the discovery of new sites, investigation of cultural landscapes, condition assessment of heritage assets and monitoring and modeling of impacts due to natural hazards and human threats. There is still the need for translating this expertise, spread across the globe, into capacity, best practices, and tools made available widely (Tapete, 2018).

The rapidly growing global population places cultural heritage at great risk, and the encroachment of modern settlement on archaeological sites means that valuable information about how past societies worked and interacted with the environment is lost. To manage and mitigate these risks, we require knowledge about what has been lost and what remains, so we can actively decide what should be investigated and what should be 
preserved for the future (Stott et al., 2018). Several scientific and archaeological studies of south Asia started with the European colonization of some areas in Sindh in the mid-eighteenth century. Renaudot (1733AD) describes Arab travelers and merchants for a colony of an ancient town of Sindh during 9th and 10th centuries AD (Panhwar, 1983). Runnel (1782-1785AD) was the first official cartographer of the British who produced maps of tributaries of the Indus delta and coast of Sindh based on several historical sources (Panhwar, 1983).

In half of million years (Paleolithic period or stone age) a very rich and cultured capital city, the oldest and the first civilization of south Asia, is represented at MohenjoDaro. There is the largest necropolis of the muslim rulers, saints, and men of rank at Makli hill, Thatta and heritage represented in Sindh. Remains of one of oldest civilization are Indus or Harappa situated in Pakistan and there are early Islamic metropolitan centers and include Pakistan's earliest mosque at Banbhore, Mansurah. This mosque was the first Ranikot and is the largest fort of south Asia, located in Sindh.

Some archaeological evidence has been discovered from the excavations done at the settlements of Mansurah and Banbhore (identified with Debal) and contemporary settlements at Naro Waro Dharo, Jhukar, Allah dino and Lakhueen Jo Daro which belong to the Indus civilization namely, Kot Diji and Amri. In the past, archaeological excavations have been carried out at 14 sites which belong to the upper Paleolithic or late stone Age periods. These are early settlements of the fourth and second millennia $\mathrm{BC}$, down to the late Muslim period or until the middle of 19th century AD (Mughal, 1998).

The Thatta district is situated at a distance of about 92 $\mathrm{km}$ east of Karachi (Fig.1). Geographically Thatta is bounded by district Badin and Tando Muhammad Khan in the east, Hyderabad and Jamshoro district on the North, Karachi on the west and the Arabian sea on the south. There are nine Talukas in this district. Thatta was an important city for being Sindh's capital. From the 14th century four muslim dynasties ruled Sindh from Thatta. Thatta has a very rich heritage of muslim architecture during the era of the 16th and 17th centuries. The history of Thatta is about 2000 years. Fig. 2 shows the study area highlighting the areas of Makli graveyard and Banbhore fort.

Objectives. This research has the following objectives:

- To identify the archaeological sites of Makli Graveyard and Banbhore fort through satellite image,

- To explore the major land cover pattern on the Southern part of Sindh Province using Geo-Spatial Technologies and

- To visualize the Digital Elevation Model (DEM) on the southern part of Sindh province.
Study Points
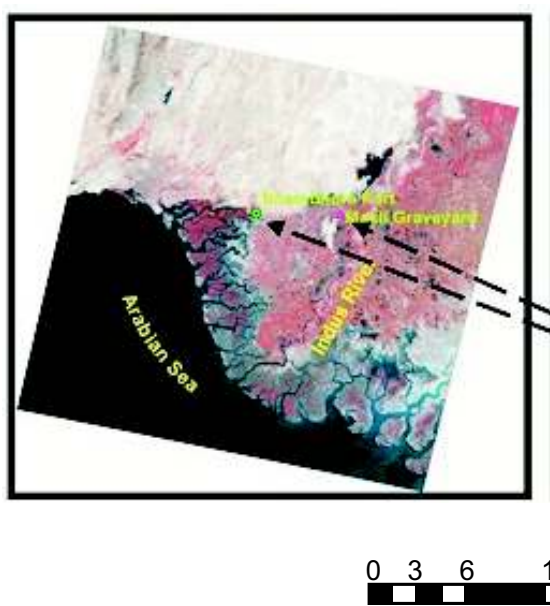

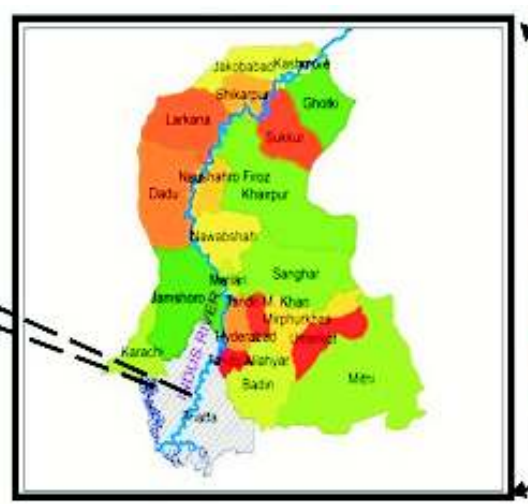

Kilometers
Pakistan

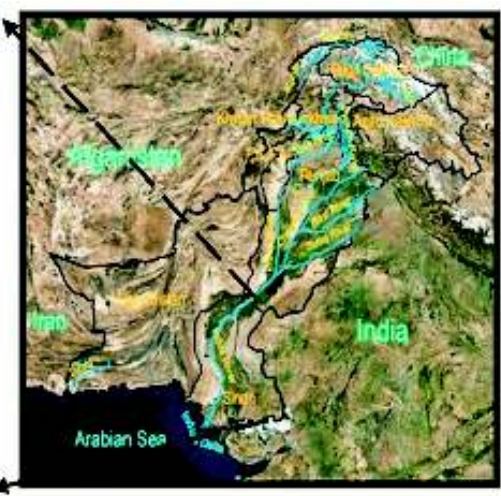

Study Area

H Bhambhore Fort

9 Maki Graveyard

Fig. 1. Study area. 


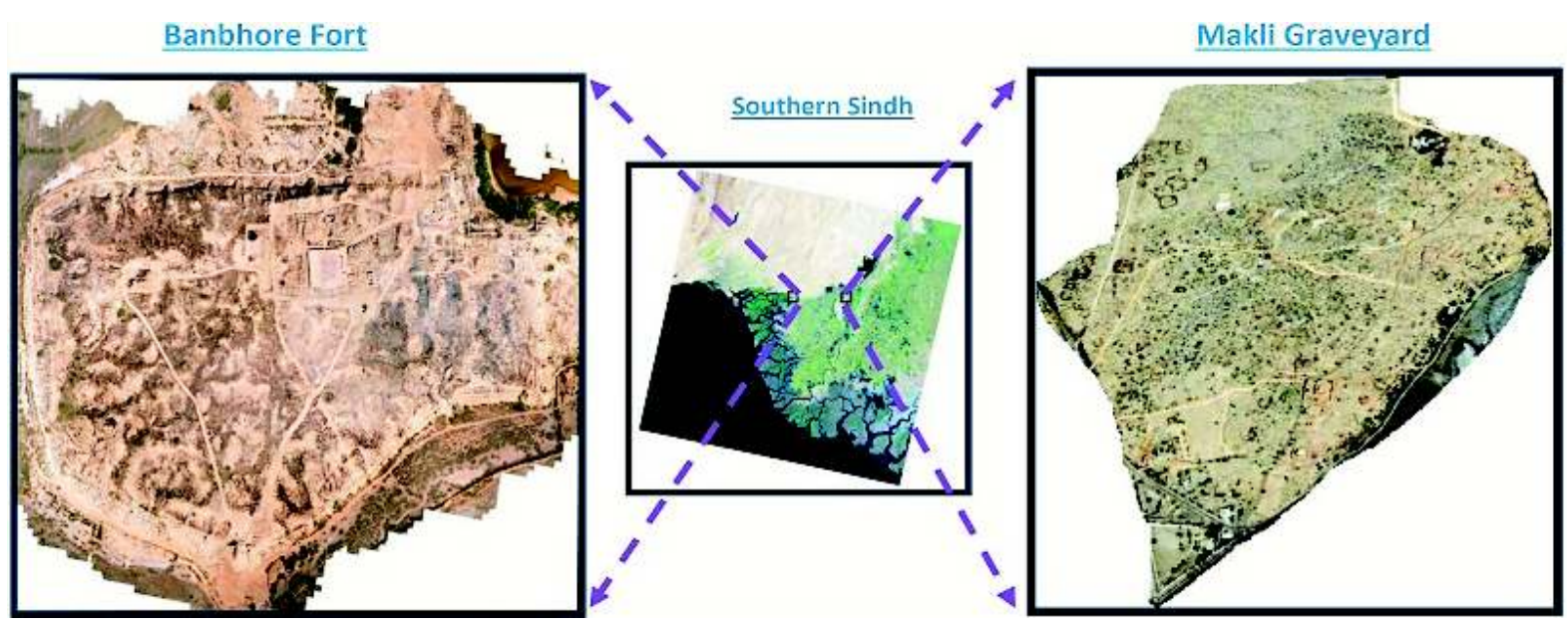

Fig. 2. Overview of study area.

\section{Material and Methods}

The study is based on satellite remote sensing and GIS application. The satellite images of Landsat-8 OLI/ TIRS dated $20^{\text {th }}$ December -2014 and a Digital Elevation Model (DEM) were downloaded from the official earth explorer USGS distribution website (earthexplorer. usgs.gov) and Google Earth imagery were used for this study. GPS based field surveys of the archeological sites were conducted.

Supervised classification, defined informally as the process of using samples of known identity to classify pixels of unknown identity was conducted on the remotely-sensed images (Campbell, 2002). Samples of known identity on ground are pixels located within training areas (Sohail, 2012; Campbell, 2002), Supervised classification of the acquired images was carried out using ERDAS Imagine 2013.

\section{Results and Discussion}

Land cover of the study area has been classified into four different classes namely vegetation, Barren / vacant land, mudflat and wet soil and water body (Fig. 3). The rapidly growing of population and global warming place cultural heritage sites at great risk. According to Rehman et al., 2019, the land cover classes and socio-economy of upper and central Sindh province is under the dangerous threat of climate change, especially in flood period. According to his study, normal vegetation, water body and wet soil are decreased while healthy vegetation and dry soil are increased (Rehman et al., 2019).
Makli graveyard. The Makli hill near Thatta is the world's biggest graveyard spread more than $15.5 \mathrm{~km}^{2}$ having millions of graves. Here inside lie lords, queens, philosophers, researchers and soldiers of a by-gone period a time prestigious for its way of life and learning. It is believed that this was the spot where Alexander the great rested his armies after their long walk. The encompassing region incorporates the barren and rocky Kohistan area and the swampy deltaic land of the Indus plain, adjacent excavations uncover the occupations dating from the first century.

There are landmarks of Summa period $\left(14^{\text {th }}\right.$ to $16^{\text {th }}$ centuries), the Tarkhan and Arghun period (16th century), and the Mughal period ( $16^{\text {th }}$ to $18^{\text {th }}$ centuries). The structure and tombs are solid and wonderful epitomizing in Mughal governors. The fundamental stones utilized as a part of the development of these landmarks are marble and granite which tend to keep going for eras. The biggest and the most noteworthy among the tombs is that of Isa Khan Tarkhan who passed away in 1644. After the finishing of a tomb, Isa Khan cut off the hands of most skilled craftsmen, so that no other ruler could duplicate the same landmark again. Among the most protected monuments are the tombs of Mirza Jani Beg, Mirza Tughral Beg, and Diwan Shurfa Khan.

In the Thatta district, there is the Shah Jehan mosque, which is the perfect work of art of Mughal development. This mosque is a work by the constructor of the Taj Mahal in 1647 A.D. It was created in the middle of the $17^{\text {th }}$ century and is a wonderful example of muslim 


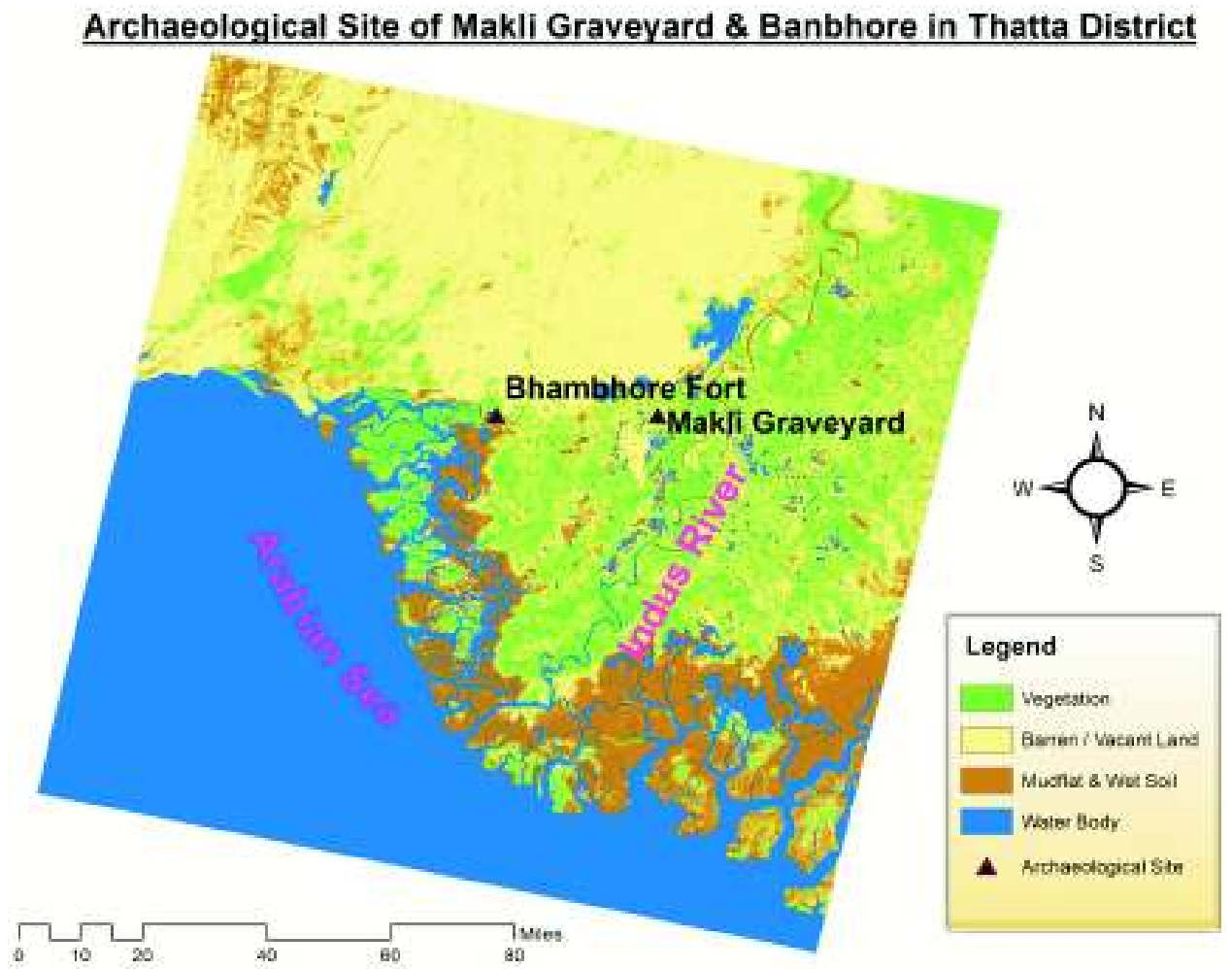

Fig. 3. Land-use/land cover classification of southern Sindh.

architecture and heritage. This mosque was the work of Mir Abdullah at the request of the Mughal head Shah Jehan. The Shah Jehan mosque is a superb example of craft tile work. Its 93 domes and 33 arches with varying sizes make it a beautiful architecture. The domes have been dazzlingly laid in a mosaic of transmitting blue and white tiles.

Figure 4 shows the satellite image of Makli graveyard and indicates various locations. The majestic tomb of Mirza Isa Khan Turkhan is shown on the right side of the figure. On the bottom and right of the figure are the gravestones that mark the four muslim dynasties that reigned over the area.

Banbhore. Banbhore is also an archaeological site, situated around $64 \mathrm{~km}$ east of Karachi on the Gharo Greek, which is an old branch of the Indus river. It consists of a fortified settlement measuring about two thousand by one thousand feet. There is an outer unwalled area in north of the city where archeological excavations revealed a well-planned city. Some scholars identify the sites of Banbhore as Debal, the scene of the first victory of the Arabs where the Arab general

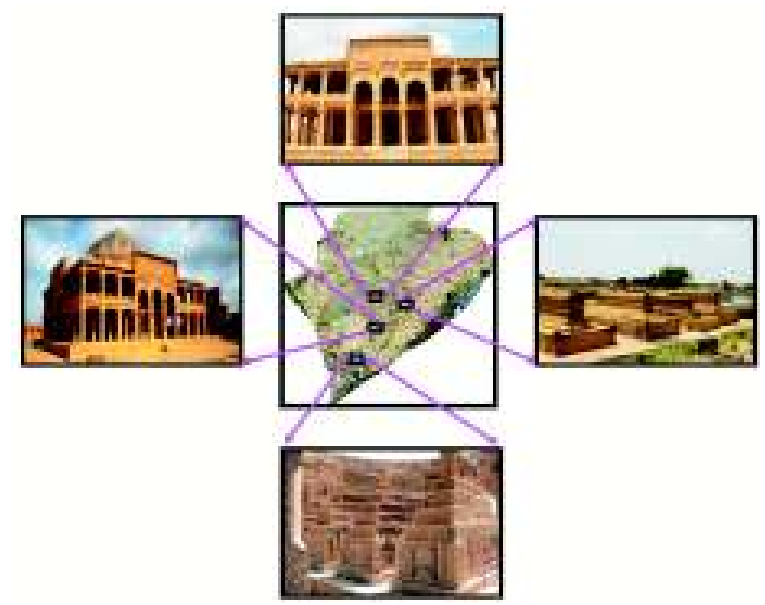

Fig. 4. Architectural structures in various locations of the Makli graveyard.

Muhammad bin Qasim entered in Sindh entered Sindh in 712 AD (Mughal, 1998). After a young general conquered the city, Muslims built mosques and other residential buildings and fifteen walls around the town. 
Banbhore is also associated with the famous romance of Sassi and Punhu admired by Sufi poets and folklore. Sassi belonged to Banbhore. The museum at the site houses a rich collection of painted pottery, coins, beads and other artifacts. About the 10th century it was the capital of the chief Bhambor Raja and was named Bhambor after him. This town was later destroyed in 1250 A.D (Mughal, 1998).

In the center of a semi-circular palatial building remains of a mosque with numerous Kufic inscriptions carved on dressed stone slabs revealing that this was the earliest known mosque of the sub-continent. Its discoveries throw light not only on the Muslim era but also on premuslim times. They tell us about the civilization of early centuries of the christian era. Some human skeletons have also been found in streets and houses. The hindu temple of the pre-muslim era has also been unearthed along with coins belonging to Khilafat period. Other stone, glass and ivory objects, pottery, jewelry, arms and certain human skeletons with arrows in their heads show that this town came to a violent end.

The diggings were done at four major areas which revealed an elaborate gateway system, domestic and public architecture and grand mosque located in the middle of the city. The first occupation belongs to the Scythe-Parthian period representing at least three centuries. Beginning from the first century $\mathrm{BC}$ this type of pottery provides precise parallels with that found by sir John Marshal at the first city of textiles where it is dated to the first century BC period. The second major culture horizon at Banbhore has been identified with the Hind - Sassanian period in the $5^{\text {th }}$ century AD. They were in great competition with the Roman traders and had monopolized the sea routes to the subcontinent. The third major culture period belongs to the early Islamic times which represents six centuries consisting of the Umayyad (711-750 AD) period. A good number of gold, silver, and copper artifacts were found in the excavations which helped to assign precise dates not only to the building but also to the cultural materials.

This is the site of a large town that existed at least 1400 years ago. The pieces of pottery found by archaeologists are similar to those found at Taxila and known to be of the 1 st century B.C. Banbhore has given museums a strong archaeological heritage. One which attracts tourists from all corners globe.

Figure 5 shows the satellite image of Banbhore fort and indicates various locations with the Banbhore fort on top. At the bottom and right of the Figure, the Gharo creek and lake of the area are shown. On left side is a dome-like fort structure.

Digital elevation model (DEM). The huge sediment load of the Indus river led to the formation of a broad alluvial valley $(150 \mathrm{~km}$ wide on average in the lower basin between the hills of the Kirthar range in west and the sand dunes of the Thar desert in the east (Fig. 6) (Giosan et al., 2006). The shelf of the Indus Delta remains largely unstudied. Its most prominent feature is the Indus Canyon or the Swatch, a relic feature of the pre-holocene relief (Fig. 6), which

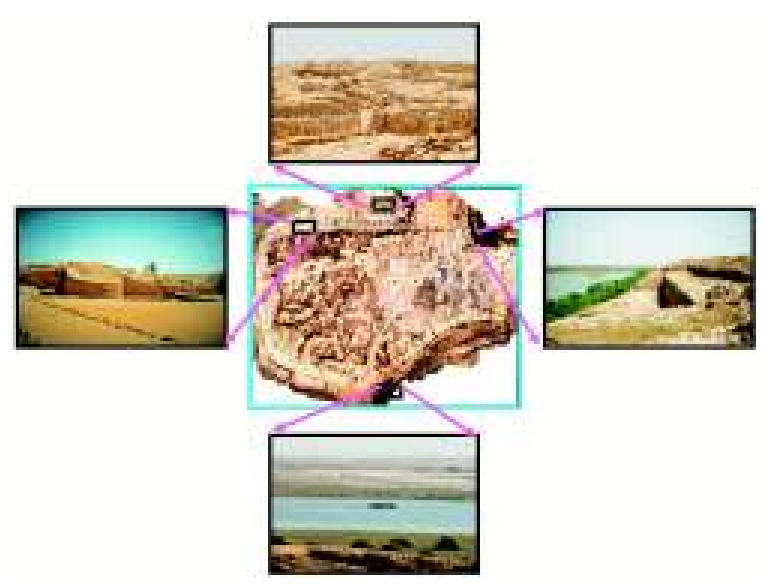

Fig. 5. The various location of Banbhore fort.

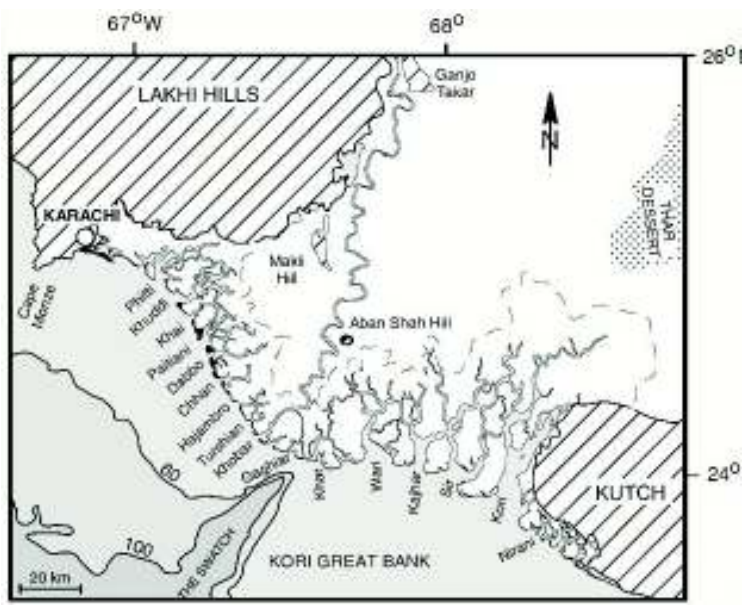

Fig. 6. Map of the southern Sindh (Indus delta region) and several sandy barrier islands front the delta coast (black-filled pattern). (Source: Giosan et al., 2006) 
dissects the shelf to within $24 \mathrm{~m}$ water depth. The DEM shows elevation of vegetation and barren / vacant land is 4 to $17 \mathrm{~m}$, with high elevations around 131 to $314 \mathrm{~m}$ in the Lakhi hills shown in Fig. 7. The map also shows the southern Sindh (Indus delta region) and several sandy barrier islands which front the delta coast (black-filled pattern).

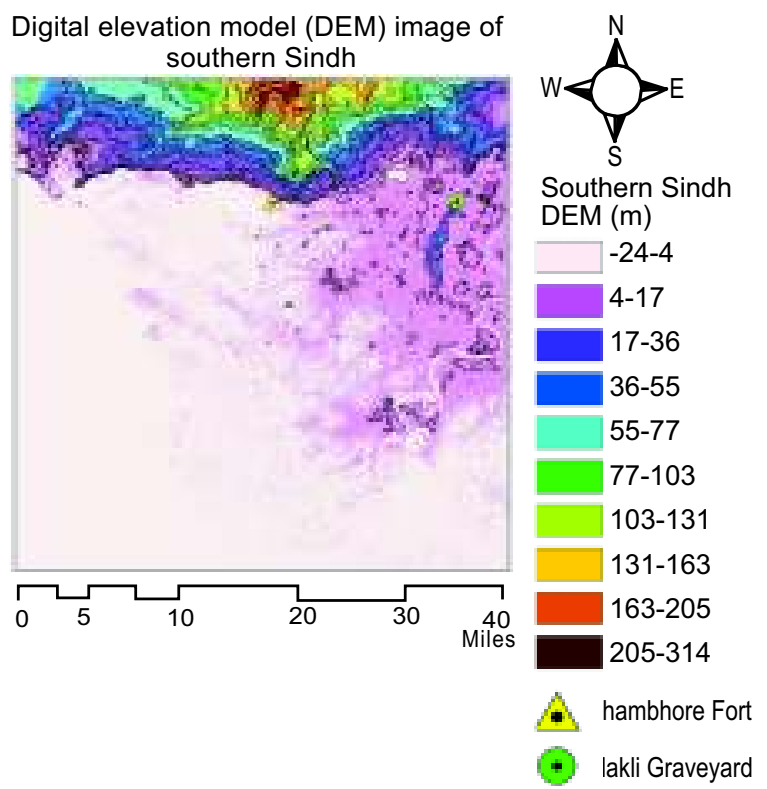

Fig. 7. Map of the DEM of southern Sindh

\section{Conclusion}

Remote sensing and GIS technologies have provided a powerful set of tools to analyze the past and present human life ways, archaeological and socio-economic patterns, environmental management, predictive site location modeling, and producing topographical site surveys. However, remote sensing is a very large and dynamic field which incorporates much more than just satellite images. In the way to preserve the archaeological heritage GIS represents a useful tool set. It allows monitoring archaeological evidence and helps to define recovery and preservation action. As this study illustrates the strength of a GIS is demonstrated by its utility as a tool for visualization, data exploration, and data generation. The GIS of the future will possess threedimensional capabilities that will open up new lines of inquiry for spaces such as topologically complex caves. From the evidence, the settlement of Banbhore fort might have been destroyed by earthquakes and invading people during the latter half of $12^{\text {th }}$ century AD.
Banbhore has survived such threats and continued to flourish as the only and most important port of Sindh. The historical monuments at Makli, and Banbhore fort testify in an outstanding manner to the civilization of the Sindh region. Geographically its location is vulnerable around the river.

\section{Acknowledgment}

Authors are grateful to Mr. Sirfaraz Ahmed, surveyor, from Department of Antiquities, Government of Sindh for assistance, guidance and support during the research work.

Conflict of Interest. The authors declare that there is no conflict of interest

\section{References}

Campbell, B.J. 2002. Introduction to Remote Sensing. $3^{\text {rd }}$ ed., Taylor and Francis, London, UK.

Giosan, L., Constantinescu, S., Clift, P.D., Tabrez, A.R., Danish, M., Inam, A. 2006. Recent morphodynamics of the Indus delta shore and shelf. Continental Shelf Research, 26: 1668-1684.

Lieff, S. 2006. Applications of Geographic Information Science in the Archaeological Research of the Fincastle Kill Site (D1Ox 5) Alberta, Canada, and Tel Beth-Shemesh, Israel (Doctoral Dissertation,) Faculty of Arts and Science, University of Lethbridge, Canada.

Moyes, H. 2002. The use of GIS in the spatial analysis of an archaeological cave site. Journal of Cave and Karst Studies, 64: 9-16.

Mughal, M.R. 1998. The Archaeology of Sindh (Since 1930) Update Supplement to Antiquities of Sindh. 969: 8 .

Nsanziyera, A., Rhinane, H., Oujaa, A., Mubea, K. 2018. GIS, Remote-sensing application in archaeological site mapping in the Awsard area (Morocco). Geosciences, 8: 207.

Panhwar, M.H. 1983. The Development in the Study of History and Archaeology of Sindh, https://panhwar. com/Article173.htm

Peppa, M.V., Mills, J.P., Fieber, K.D., Haynes, I., Turner, S., Turner, A., Douglas, M., Bryan, P.G. 2018. Archaeological feature detection from archive aerial photography with a SfM-MVS and image enhancement pipeline. International Archives of Photogrammetry, Remote Sensing and Spatial Information, 42: 869-875 
Rehman, Z., Ur, Mahar, G.A., Chandio, N.H., Iqbal, M.J., Kazmi. J.H. 2019. Appraisal of land cover changes in the upper Sindh through geo-informatics techniques. Sindh University Research JournalSURJ (Science Series), 51: 141-146. http://sujo-old. usindh.edu.pk/index.php/SURJ/article/view/4879

Sohail, A. 2012. Mapping land cover/land use and coastline change in the eastern Mekong delta (Viet Nam) from 1989 to 2002 using remote sensing. MSc. Thesis in Bioinformatics, TRA-GITEX 12-
007, 76 pp., School of Architecture and the Built Environment, Royal Institute of Technology (KTH), Stockholm, Sweden. ISSN 1653-5227.

Stott, D., Kristiansen, S.M., Lichtenberger, A., Raja, R. 2018. Mapping an ancient city with a century of remotely sensed data. Proceedings of the National Academy of Sciences, 115: E5450-E5458.

Tapete, D. 2018. Remote sensing and geosciences for archaeology. Geosciences, 8: 41 doi:10.3390/geosciences 8020041 